\title{
THE IMPACT OF ETHNIC ENTREPRENEURSHIP ON THE INNOVATIVE DEVELOPMENT OF THE ECONOMIC SPACE OF A POLYETHNIC REGION
}

\author{
MUKHA N. Victoria ${ }^{1}$, KLOCHKO N.Elena ${ }^{2}$ \\ ${ }^{1}$ Kuban State Technological University, Krasnodar (RUSSIA) \\ ${ }^{2}$ Kuban State Agrarian University, Krasnodar (RUSSIA) \\ E-mails: sfmsmu@mail.ru; 651728@mail.ru
}

\begin{abstract}
In modern conditions, socio-economic development of regions implies searching for new opportunities and forms of doing business, for instance, making use of the ethno-social potential of territories, and ethnic entrepreneurship.

The purpose of the present article is to analyse the opportunities of ethnic entrepreneurship as a resource for the development of the economic space in polyethnic regions. Ethnic entrepreneurship is studied through the prism of the interdisciplinary approach, which allows analysing the concept as both an economic and a sociocultural phenomenon. The article also presents the secondary analysis of the findings of sociological research.

In the course of research, it has been found that the two subjects of ethno-entrepreneurial activity are ethnic migrants and ethnic minorities (or the ethnic majority) that are engaged in traditional economic activities. Each of the subjects employs its own ethno-economic development strategy, which is to be taken into account in the general economic development of a certain territory. The conclusion has been made that ethnic entrepreneurship is an established region-specific economic practice, which provides new opportunities for territorial development.
\end{abstract}

Keywords: socio-economic system, polyethnic region, ethnic migrants, economic niches, ethnic entrepreneurship, ethno-economy, ethno-economic paradigm, economic space of the region.

JEL: L26

DOI: 10.5937/intrev2103015M

UDC: 332.158

005.73:[316.75:323.1

COBISS.SR-ID 55042057 


\section{INTRODUCTION}

The process of globalization, its consequences and prospects have been heatedly discussed by the scientific community for several decades. Recognizing its integrity and contradictory effect on society, some researchers highlight that globalization increases regionalization and intensifies the ethnic factor [1][2][3]. This is exactly what R. Robertson called "glocalization", or an organic combination of the global and the local in different areas of public life [4]. Glocalization is an attempt to adapt multinational business to local conditions [5][6][7][8][9]. Meanwhile, the processes of glocalization are region-specific, depending on the resource base of each region and its established economic practices [10][11].

In the Russian present-day reality, regional socio-economic development is associated with the challenges caused by the pandemic, high unemployment rates, the outflow of rural population, income inequalities by municipalities, etc. These circumstances necessitate diversifying the structure of the regional economy, searching for new opportunities and ways of doing business, and making use of socioeconomic potential of territories and their ethnic diversity. The impact of polyethnicity on the development of the Russian economy is viewed differently by different scientists. Some suggest it has a significant contradictory influence and does not contribute to economic development but increases social inequality. Others, V. Tishkov in particular [12][13][14][15][16], tend to believe that it is exactly ethnic diversity that intensifies the introduction and development of innovative forms of business, promotes mutual contribution of ethnic groups into each other's economic practices, and encourages growth.

One of the examples of the ethnic factor in the economy is ethnic entrepreneurship. Its resource capacity for the economic space development in polyethnic regions is analysed further in the article.

\section{THEORY AND LITERATURE REVIEW}

Initially, ethnic entrepreneurship was regarded as a form of adaptation of migrants to a new environment, a form of employment and financial provision [17][18]. As a rule, ethnic migrants have a poor command of the language of a host community, experience difficulties with residence registration, and often cannot prove their qualification, which results in their limited employment opportunities. Therefore, the entrepreneurial activity may be just about the only way for them to survive in a new society [19][20][21][22][23].

However, as both real practice and further research into this phenomenon have shown, it is not only migrants that can be engaged in ethnic entrepreneurship, but also the population permanently residing in a given territory, who either make use of their ethnic ties or produce ethnically-targeted products/ provide ethnically-targeted services in order to make a profit [24][25][26][27].

It is important to mention that researchers have not yet reached a consensus on how the concept of ethnic entrepreneurship should be defined (Table 1).

Table 1 - Definitions of ethnic entrepreneurship

\begin{tabular}{|l|l|}
\hline \multicolumn{1}{|c|}{ Author } & \multicolumn{1}{c|}{ Definition } \\
\hline R. Waldinger & $\begin{array}{l}\text { A set of connections and regular patterns of interaction among people sharing } \\
\text { common national background or migratory experiences [29] }\end{array}$ \\
\hline A.A. Susokolov & $\begin{array}{l}\text { Concentration of residential or transient population, representing an ethnic } \\
\text { minority in certain economy sectors of a given region [30] }\end{array}$ \\
\hline A. Snisarenko & $\begin{array}{l}\text { A specific way of organizing and operating a business of ethnic minority in the } \\
\text { environment of another nation. [31] }\end{array}$ \\
\hline A.N. Sadovoy & $\begin{array}{l}\text { The process that allows fulfilling the adaptive potential of ethnic groups at all } \\
\text { levels of social organization of ethnic minorities (ranging from households to } \\
\text { large companies), and integrating the primary institutions of ethnic groups } \\
\text { (fractals) into the system of regional and interregional economic relations, with } \\
\text { the account of their ethnic self-definition[32] }\end{array}$ \\
\hline
\end{tabular}

As can be seen, the concept of ethnic entrepreneurship is rather vaguely defined, but all given definitions have a focus on the ethnicity of business agents (migrants or ethnic minorities). However, these definitions do not take into account the ethnic majority, although it can also be engaged in this type of economic activity. 
From the perspective of the authors of this article, it is more rational to understand ethnic entrepreneurship through products manufactured. S.P. Tyukhteneva, for instance, suggest defining ethnic entrepreneurship as "a type of economic activity, in which an entrepreneur makes use of their ethnic and community relationships and family ties when manufacturing products or providing services that are in demand in a given ethnocultural community, and delivering them to be consumed both inside and outside their ethnic community" [28]. Ethnic products and services can come in a wide variety of forms: food production, national cuisine restaurants, ethnic tourism, ethnic beauty and medical services, etc. The key feature of these products and services is that they preserve and present the characteristics of the culture and lifestyle of a particular ethnic community. Ethnic products and services can be highly marketable and can develop into a successful business.

Summarising the ideas on ethno-entrepreneurial activity, it should be mentioned that it has two groups of agents: 1) ethnic migrants who find themselves in a new ethnic environment and rely on entrepreneurship for survival and adaptation to different circumstances; 2) ethnic minorities that have historically inhabited the territory or have arrived and assimilated into the community, or the ethnic majority engaged in traditional economic activities who consider ethnic entrepreneurship as a way to preserve their ethnic and ethnocultural identity.

Based on the analysis of the works by Russian and foreign scientists, S.P. Tyukhteneva proposed the following model of ethnic entrepreneurship (Figure 1):

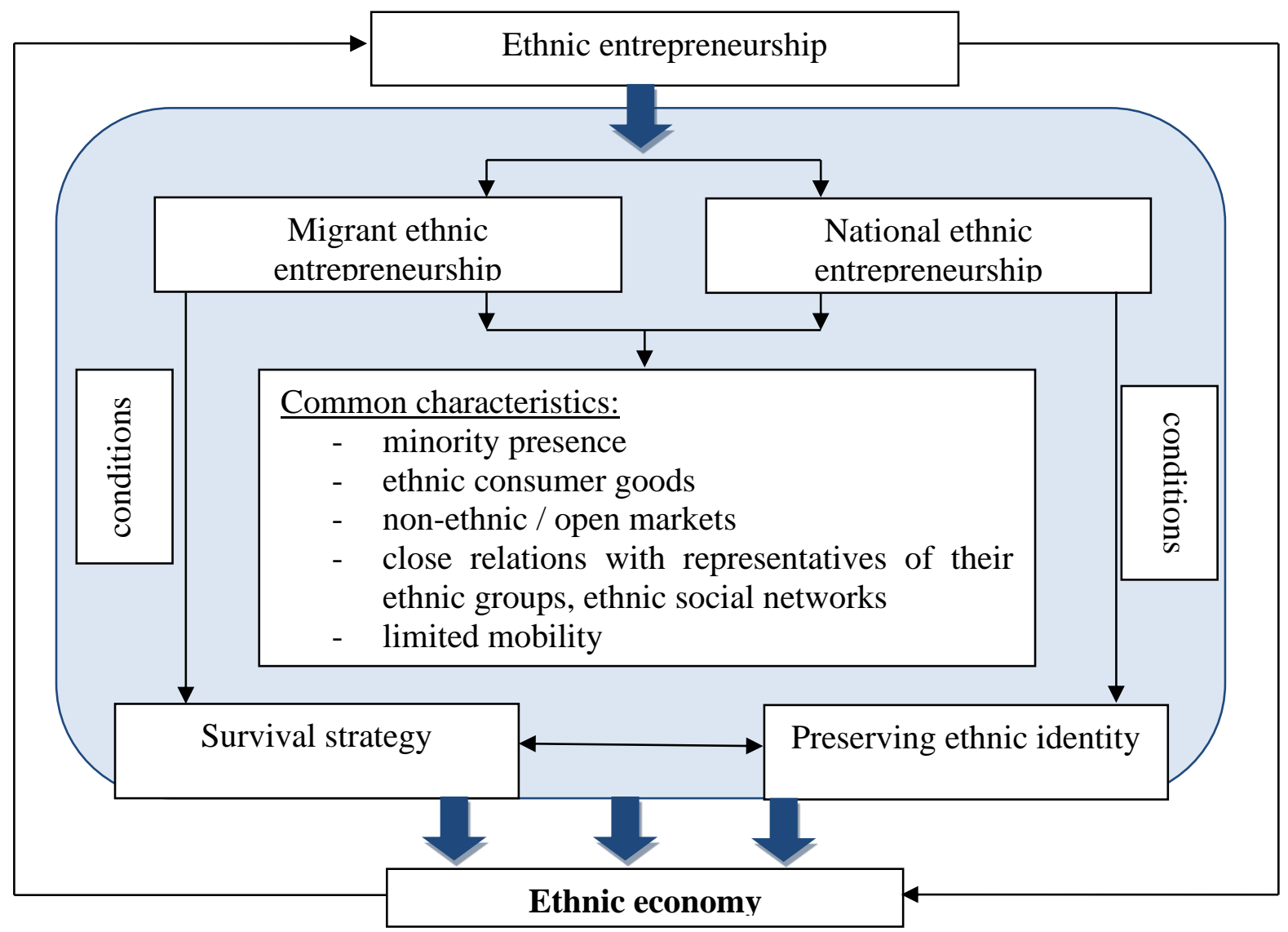

Fig. 1 - The structure of ethnic entrepreneurship [33]

This model clearly demonstrates the common and specific features of the ethnic entrepreneurship groups. Business activity of these groups contributes to the development of ethnoeconomy, which in turn affects ethnic entrepreneurship. 


\section{RESULTS AND DISCUSSION}

In order for ethnic entrepreneurship to become a key resource for the economic development of both a region and the country in general, it is essential to ensure that the necessary conditions have been provided, which include a required level of economic development, a relevant regulatory and legal framework, and certain aspects of migration policy, etc. On the other hand, it is also important for the population to be ready for entrepreneurial activity and to acknowledge both entrepreneurship itself and the opportunities for starting a business. Presented below are the findings of sociological research conducted by major research centres on the subject.

According to the results of the survey carried out by the Russian Public Opinion Research Centre (VCIOM), the majority of Russians (89\%) perceive entrepreneurship positively, with only $6 \%$ having negative attitude towards it (in 2009, they amounted for 13\%). Meanwhile, the majority of the respondents (62\%) tend to believe that it is not possible to do fair business in Russia; however, in comparison with 2009 , the number of sceptics has decreased.

Table 2: Attitudes of Russian people to entrepreneurs (small and medium-sized businesses), \%

\begin{tabular}{|l|c|c|c|c|c|}
\hline & 2009 & 2011 & 2013 & 2017 & 2019 \\
\hline Positive & 41 & 45 & 41 & 56 & 48 \\
\hline Rather positive & 38 & 36 & 42 & 34 & 41 \\
\hline Rather negative & 9 & 7 & 7 & 4 & 4 \\
\hline Negative & 4 & 5 & 2 & 4 & 2 \\
\hline Not sure & 8 & 7 & 8 & 2 & 5 \\
\hline
\end{tabular}

When asked about barriers to starting a business, the respondents named the following: high taxes (25\%), bureaucracy (22\%), heavy financial costs associated with doing business (16\%), corruption (9\%), administrative barriers (8\%), etc. The entrepreneurial activity rate is also changing: currently, $25 \%$ of the population are willing to set up a business, whereas $10 \%$ of Russians surveyed are reported to already have a business of their own (in 1991, they were $2 \%$ only)[34.

The results of the Global Entrepreneurship Monitor survey conducted internationally, also demonstrate profound changes. According to the 2019-2020 data, the entrepreneurial activity of Russians reached its record high level - in 2019, $9.8 \%$ of the adult working-age population of the country were planning to set up their own business within the following three years. The main motivation for Russians to start their own business is ensuring income. $78 \%$ of respondents agreed that entrepreneurial activity is a way to make money when other job opportunities are limited, and $69 \%$ associate business with higher income earning opportunities and financial well-being. For $25 \%$ of respondents, it was family tradition that encouraged them to start business [35].

In general, the necessary conditions for the development of entrepreneurship in Russia have been provided, and a positive public perception of business has been shaped.

\section{CONCLUSIONS}

In the Russian present-day reality, both the operation of ethnic entrepreneurship and its research prove challenging. Due to the peculiarities of the business registration procedure, it is difficult to obtain reliable statistical data on the number of ethnic entrepreneurs. In Russia, ethnic entrepreneurship is an established economic practice having its regionals specific features: in some regions, it has organically integrated into the existing business environment, in others it is facing intense competition, while in yet others it is trying to monopolize certain economic niches. In order for ethnic entrepreneurship not to be considered a constraint, but a key resource for the innovative development of the economic space in the region, it is critical to perceive the ethnic diversity of territories as a social resource.

\section{ACKNOWLEDGMENTS}

The research was carried out with the financial support of the Kuban Science Foundation in the framework of the scientific project № FNI-GO-20.1/11 


\section{REFERENCES}

[1] Friedman, T. L. (2000). The Lexus and the olive tree: Understanding globalization. Farrar, Straus and Giroux.

[2] Hirst, P., Thompson, G., \& Bromley, S. (2015). Globalization in question. John Wiley \& Sons.

[3] Gunter, B. G., \& Wilcher, B. (2020). Three decades of globalisation: Which countries won, which lost?. The World Economy, 43(4), 1076-1102.

[4] Robertson, R. (1992). Globalization: Social theory and global culture (Vol. 16). Sage.

[5] Roudometof, V. (2016). Glocalization: A critical introduction. Routledge.

[6] Sedlyar, M.O. (2019). Glocalization of the country's innovative development. Management in social and economic systems, (28), 161-162.

[7] Lambregts B, Beerepoot N and Kloosterman RC (2016) The Local Impact of Globalization in South and Southeast Asia: Offshore business processes in services industries. London and New York: Routledge.

[8] Beretta, E., \& Cencini, A. (2020). Double-entry bookkeeping and balance of payments: the need for developing a new approach. Insights into Regional Development, 2(3), 610-629. https://doi.org/10.9770/IRD.2020.2.3(1)

[9] Gorelik, O.V., Brjanzev, A.Y., Safronov, S.L., Gritsenko, S.A., \& Bobkova, E. (2021). Influence of the age of cows on the dynamics of dairy efficiency depending on a breeding line. IOP Conference Series: Earth and Environmental Science, 2021, 677(4), 042015

[10] Beck, U. (2018). What is globalization? John Wiley \& Sons.

[11] Dudukalov, E. V., Rodionova, N. D., Sivakova, Y. E., Vyugova, E., Cheryomushkina, I. V., \& Popkova, E. G. (2016). Global innovational networks: Sense and role in development of global economy. Contemporary Economics, 10(4), 299-310. doi:10.5709/ce.1897-9254.217

[12] Tishkov, V. (2005). Market economy and ethnic environment. Society and Economics, (12), 20-37.

[13] Sadovoy, A. N. (2017). Ethnic economy. To the analysis of traditional social institutions of minorities. History and Computer Association Newsletter, (46), 113-117.

[14] Belousova, M., Aleshko, R., Zakieva, R., Karabasheva, M., Gorovoy, S., \& Kozhemov, S. (2021). Development of equipment management system with monitoring of working characteristics of technological processes. Journal of Applied Engineering Science, 19(1), 186-192. doi:10.5937/jaes028855

[15] Magsumov, T.A. (2014). Main approaches to the study of historical and educational process. Bylye Gody, 34(4), 720-726.

[16] Pogosyan, V. (2019). Change And Variability Of Phenomena In Complex Social Systems. WISDOM, 13(2): 95-103. DOI: https://doi.org/10.24234/wisdom.v13i2.276

[17] Rozhkova, L.V. (2009). Entrepreneurship as a way of social adaptation of ethnic migrants. Proceedings of higher educational institutions. Volga region. Humanities, (2).

[18] Ryazantsev, S.V. (2000). Ethnic entrepreneurship as a form of adaptation of migrants. Social Sciences and Modernity, (5), 73-86.

[19] Kuznetsov, I., Mukomel, V. (2007). Formation of ethnic niches in the Russian economy. Debate on Politics and Culture, (1), 175-184.

[20] Kloosterman, R. C., Rusinovic, K., \& Yeboah, D. (2016). Super-diverse migrants - similar trajectories? Ghanaian entrepreneurship in the Netherlands seen from a Mixed Embeddedness perspective. Journal of Ethnic and Migration Studies, 42(6), 913-932.

[21] Hatziprokopiou, P., Frangopoulos, Y., \& Montagna, N. (2016). Migration and the city: Diversity, migrant economies and urban space Introduction.

[22] Yemelyanov, V.A., Fatkulin, A.R., Nedelkin, A.A., Titov, V.A. \& Degtyarev, A.V. (2019), "Software for weight estimation of the transported liquid iron", Proceedings of the 2019 IEEE Conference of Russian Young Researchers in Electrical and Electronic Engineering, ElConRus 2019 , pp. 381.

[23] Ivanova, V., Poltarykhin, A., Szromnik, A., \& Anichkina, O. (2019). Economic policy for country's digitalization: A case study. Entrepreneurship and Sustainability Issues, 7(1), 649-661. doi:10.9770/jesi.2019.7.1(46)

[24] Rath, J., Solano, G., \& Schutjens, V. (2020). Migrant entrepreneurship and transnational links. Sage handbook of international migration, 450-465. 
[25] Rahman, P. A. (2017). Analysis of the mean time to data loss of nested disk arrays RAID-01 on basis of a specialized mathematical model. IOP Conference Series: Materials Science and Engineering, 177(1). https://doi.org/10.1088/1757-899X/177/1/012088

[26] Bykanova, O.A. \& Akhmadeev, R.G. (2019). Universal VAT Loyalty Policy for B2B E-Commerce. Proceedings of the 34th International Business Information Management Association Conference, IBIMA 2019: Education Excellence and Management of Innovations through Sustainable Economic Competitive Advantage, 3046 - 3051

[27] Lyubashits, V. Ya., Razuvaev, N. V., Abramova, I. E., Fedorova, N. V., \& Benedyk, Y. S. (2020). Political Institute of the State in the Context of the Historical and Typological Analysis. Revista Genero \& Direito, 9(3), 726-741. Retrieved from https://periodicos.ufpb.br/index.php/ged/article/view/51909

[28] Tyukhteneva, S.P. (2018). Ethnic entrepreneurship without migration: the cases of Tuva and Kalmykia). New Research of Tuva, (2).

[29] Waldinger R., McEvoy D., Aldrich H. (1990) Spatial dimensions of opportunity structures. Ethnic Entrepreneurs: Immigrant Business in Industrial Societies.

[30] Susokolov, A.A. (2006). Culture and exchange. An Introduction to Economic Anthropology. Moscow, 212-214.

[31] Snisarenko, A. (1999). Ethnic entrepreneurship in a large city of modern Russia (on the example of the study of the Azerbaijani community of St. Petersburg). The informal economy. Russia and the World / Ed. by T. Shanin. Moscow, Logos, 138-155.

[32] Sadovoy, A. N. (2019). Methodological aspects of the analysis of traditional forms of ethnic entrepreneurship. Scientific Dialogue, (8).

[33] Runova, N. Yu. (2021). Ethnic entrepreneurship: an analysis of basic definitions. Economics, Entrepreneurship and Law, 11 (2), 323-332.

[34] Entrepreneurship in Russia: the attitude of Russians and barriers. Available at: https://wciom.ru/analytical-reviews/analiticheskii-obzor/predprinimatelstvo-v-rossiiotnoshenie-rossiyan-barery

[35] National Report "Global Entrepreneurship Monitor". Russia 2019/2020. Available at: https://gsom.spbu.ru/images/cms/menu/otchet_2020-red-2n-04-06.pdf

\section{Article history:}

Received 14 October2021

Accepted 30 November 2021 